\title{
GRK3 wt Allele
}

National Cancer Institute

\section{Source}

National Cancer Institute. GRK3 wt Allele. NCI Thesaurus. Code C51180.

Human GRK3 wild-type allele is located in the vicinity of $22 q 12.1$ and is approximately 211 $\mathrm{kb}$ in length. This allele, which encodes beta-adrenergic receptor kinase 2 protein, plays a role in the phosphorylation of the agonist-bound form of the beta-adrenergic and related G protein-coupled receptors. 